academic life may influence a larger proportion to choose teaching as a vocation.

The question of the balance between teaching in arts and in science is of considerable importance. On the assumption that a good brain may be employed with equal profit in both scientific and arts subjects, the obvious solution is to deflect some of the arts students to science.

Many difficulties will be side-tracked if suggestions for bringing pressure on schools to change their outlook overnight, on local education authorities to increase their wages bill, or on teachers' unions to accept larger differentials, are avoided. All these may be desirable but, from a practical common-sense point of view, should be avoided at present because of their potential for delay. The course least prone to cause delay through vested interests would seem to be not to press for a change in the attitude of the schools but to give opportunities at university entrance for change-over to science and engineering and to provide suitable pre-entry courses for the purpose.

Although the problem is a complex one and there are many possible solutions, industry should not be asked to curtail its intake. Graduates are not being employed wastefully. The urgent need is a larger pool from which both teachers and industrial recruits can be drawn.

\section{NORTH OF ENGLAND EDUCATION CONFERENCE}

$\mathrm{A}^{\mathrm{T}}$

$T$ the North of England Education Conference, held at Morecambe on January 4, Mr. J. Chuter Ede gave the presidential address in which, reviewing the first ten years of the Education Act 1944, he said that the outstanding disappointment has been the failure to eliminate the competitive examination at the age of eleven. Inadequate effect has also been given to the principles, propounded in the White Paper which preceded the Act, of directing ability into the field where it would find its best realization, and of facilitating free interchange of pupils from one type of education to another. Other disappointments to Mr. Ede were the failure of all but nineteen of the 146 local authorities in England and Wales to submit the development plans based on the Act, which they had originally been required to do in six months, and the failure to correct the bias against craftsmanship and to do more than offer better opportunities for technical education at the secondary stage.

Mr. Ede's main plea was for unity among teachers, parents and authorities; but he offered a welcome warning against straining after uniformity and confusing this with unity. His remarks on technical education were taken up to some extent in a discussion on Tuesday morning which followed addresses by Mr. C. H. Wilson, principal of University College, Leicester, and Dr. P.F. R. Venables, principal of the Royal Technical College, Salford, on the place of the university and the technical college in higher technological education. Mr. Wilson began with a brief review of changes since the Barlow Committee in 1946 recommended the doubling of the output of university graduates in science and technology. While this was virtually accomplished by 1947 , all official statements continued to demand a greater output; but it is important to distinguish between graduates in all branches of technology and graduates in fundamental science, and between short-term and long-term requirements for either. On a short-term view, while the supply of scientists is adequate so far as industry is concerned, it is inadequate for schools ; but on a long-term view the supply of scientists seems to be reasonably adequate for some time ahead, though the best judges consider that further expansion in technology is still needed.

Discussing the adequacy of the present official policy, Mr. Wilson suggested that there may still be scope for the development of new departments of technology in the newer universities. In the long run the future of technology at the universities will be determined by four factors : the ability to forecast nationsl requirements for the different kinds of technologist; the growth in industry of $a_{0}$ much more generous view of the place of development research ; the supply by schools of students wishing to take technological degrees; and the development at universities of a consensus of opinion more congenial to the expansion of technological studies. Mr. Wilson said that he recognizes the difficulties and dangers to the academic health of the universities if any one faculty becomes out of balance, and he insisted that the universities have to face the larger questions of the place that technological studies should take in the life of the universities as a whole and the environment in which such studies are best conducted : technology is not necessarily best taught in the environment of a strongly materialistic philosophy.

Dr. Venables's paper was concerned more particularly with the technical college and with its contribution to technological education, which he distinguished carefully from technical education. Compared with the technical colleges, the universities are a small and relatively homogeneous group, and he argued that, in considering the contribution which the technical colleges could make to the expansion of higher technological education, quality not quantity of work is the essential criterion. Technological education he defined as for those who "maintain, manage and maximise industry", with special emphasis on the last two. Of the 422 institutions in England and Wales dealing to a greater or lesser degree with technical education, we need be concerned with no more than those 220 , the principals of which qualify for membership of the Association of Principals of Technical Institutions. Further, analysis of the work of these institutions, including the courses they offer, enrolments, recognition by professional bodies, their conduct of research and postgraduate facilities and regional requirements, have convinced Dr. Venables that it is essential to concentrate on some twelve to fifteen only of these institutions. Full university conditions could not possibly be created even for 44 institutions, he said, let alone 220.

Dr. Venables argued realistically that the exhortations and provisions of the Ministry of Education - Circular No. 98 on Governance, No. 94 on Research, and No. 255 on Recognized Courses of Advanced. Technology do not suffice for the further development of major technical colleges. The increased grant of 75 per cent and the recognition associated with it should on no account be made to an institution the local authority of which has not granted it a properly constituted established governing body with full powers within an approved annual financial estimate. If the local authorities will not or cannot shoulder the financial responsibility involved in the present 
grant system, the increased grant, he suggested, should be paid direct to the college and the balance recouped from one or more of the local education authorities concerned. Under such a scheme it would be possible to plan long-term developments-Dr. Venables hinted here at the quinquennial principleacademic freedom could be secured for the staff and residential hostels would be more readily forthcoming. Such major institutions would not be able to provide for all aspects of technological work, and closer links would be desirable with the industrial research associations, which have their own part to play. Nevertheless, he thought that, by increased full-time and sandwich courses, by post-advanced or postgraduate courses and by research in co-operation with industry and the research associations, and further development of management education and training, the fifteen major technical colleges he visualized could make a greatly enlarged and vital contribution to advanced technology in Great Britain.

Dr. Venables's suggestion to concentrate on twelve or fifteen major institutions was supported by $\mathrm{Mr}$. Wilson, and in the discussion Mr. D. J. Williams assured him of the whole-hearted support of the Association of Principals of Technical Institutions. Mr. Williams also advocated a separate major technical colleges committee. There was some general support, too, for the view that the present grants system is weighted in favour of the universities and the arts rather than the technical colleges and the sciences. In his address during the afternoon session on education and the administrative and financial structure of local government, Prof. S. E. Finer, University College of North Staffordshire, presented evidence that, in spite of the steady increase in educational expenditure, local authorities are still not spending nearly as much as they could and should on education; but his address did not bear very closely on the special issues raised by Dr. Venables. Prof. Finer was convinced that we need as strong a local government as can be achieved consistently with national standards, and that it is absolutely impracticable to centralize the administration of the schools. A recalculation of 1938 costs in terms of 1953 prices and school population shows that there has been virtually no increase in that part of the cost of each child's education which falls on local authorities. The real rate burden is very small and has become very much lower than before the War. The case for additional grant seems to be exaggerated, and he thought that local authorities should continue to bear the burden, subject to a reform of the education grant formula to make it more distributive, and based on a rating revaluation in 1956 with provision for a more elastic policy of exemptions and allowances in hard cases.

The sessions on January 6 were concerned with education in other countries, in which Prof. J. A. Lauwerys, University of London Institute of Education, dealt with the situation in the United States, and Dr. G. B. Jeffery, director of the University of London Institute of Education, with the position in the African Colonies. Prof. Lauwerys emphasized the diversity, the size and newness of the American system. There is urgent need, he said, for the development of educational practices which will foster the steadiness of character, power of critical thinking, independence of judgment and the vision that America's new role of leadership demands of her citizens. Of the comprehensive school, he suggested that the British would do well to study with care American experience and then try to avoid repeating the mistakes made by others : one cannot say that because comprehensive schools work in the United States they would work in Britain. On the whole, he thought that the American system is better geared than the British to the imperative requirements of an industrial and technological education, and this aspect also deserves close study. Prof. Lauwerys was also very impressed by the enormous strides which have been made during the past twenty years in developing the professional aspects of the study of education.

Dr. Jeffery's address outlined the rapid progress made by the newly created Gold Coast Government, and in the subsequent discussion Mr. A. L. Binns described the very different conditions in East Africa. Dr. Jeffery maintained that the new development plans of the African ministers to-day, which he believed are fundamentally right in the practical circumstances, in spite of foreseeable dangers, are possible only because of the efforts of missions and the Colonial Education Service over many generations. In East Africa, Mr. Binns thought that the only hope lies in a great reinforcement of the few teams of British technicians and teachers who are already raising moral and material standards in small areas, so that the effort may be sustained long enough for the development of character in African leaders when moral stamina has been undermined by the dissolution of their traditional culture. In this connexion, Mr. T. H. Baldwin urged that educationists should make it possible for British teachers to take short-term appointments in the Colonies without jeopardizing their prospects at home. On January 7, in a paper on the place of the three 'R's' in the curriculum, Miss M. V. Daniel, principal of Hereford County Training College, urged that language, whether in reading or writing, should be envisaged as the means of communicating ideas, and mathematics as an interpretation of the physical world.

\section{AGRICULTURAL CROPS: QUALITY VERSUS QUANTITY}

A MEETING of considerable significance to British agriculture was held at Cambridge during December 15 and 16 , when the National Institute of Agricultural Botany held its second Crop Conference with the theme of "Varieties in Relation to Crop Production". More than five hundred Fellows of the Institute, including farmers, seed merchants, maltsters, brewers, millers and agricultural scientists, attended to hear papers and discuss the topical problems posed by a quickly changing national and international position in relation to the production of primary agricultural products. The bulging wheat silos of North America and the threats of surpluses of coarse grain from the U.S.S.R. and other countries, coupled with a 'free market' for grain in Great Britain, acted as a stimulating, if sobering, brekground to the proceedings, and it was a matter of great interest to see how the conference quickly settled down to discuss the economics of quality versus quantity in the production of two of the three crops being consideredbarley, sugar beet and wheat.

Dr. H. Hunter introduced the subject of the barley crop, which occupied most of the first day, and 